\title{
Review of the Literature on Career Cognition in High School Students
}

\author{
Haitao Hu \\ Department of Law and Politics, North China Electric Power University, Baoding 071003, China \\ 51951261@ncepu.edu.cn
}

\begin{abstract}
This paper summarizes and summarizes the career cognition of high school students. Explore from the career cognitive level, education methods, understanding methods, and coping measures of high school students. It objectively describes the current situation and solution path of the career planning of high school students under the new college entrance examination reform.
\end{abstract}

Keywords: New College Entrance Examination; Career Planning.

\section{The Current Career Cognitive Level of High School Students}

First of all, high school students have no strong sense of autonomy, their positioning is relatively vague, and large factors from external interference. It is not enough for professional cognition, in a state of half understanding, the lack of systematic information channels. High school students are on the high school campus, and have to put learning first under both internal and external pressure, which not only makes high school students' social experience shallow, but also causes the lack of ability to distinguish right from wrong for social problems. There are two main reasons for this cognition. First, students lack comprehensive and comprehensive information access channels, and are easy to be affected by external public opinion evaluation. Second, some students are spoiled, lack of the spirit of hardship, do not have the faith and spirit of labor dedication, learning is more utilitarian.[1]

Secondly, for high school students in rural areas, their career cognition is shallow. as social competition intensifies, people must be more forward-looking about their career cognition. However, high school students in rural areas are influenced by habits and the surrounding qualitative environment, and most students lack the thinking of career development planning.From the perspective of the development disadvantages of regional, economic, political, cultural and other fields, high school students in rural areas are more vague about the future. Wang Xinjuan and Li Zibin, especially for students in rural areas, are affected by various factors such as local economic development, teachers and parents' thoughts. High schools generally lack perfect vocational planning education, which then affects the future growth and development of students.[2]

\section{The Current Way of Career Education for High School Students}

Most high school students rarely plan their career, and the subject for high school students career education is far from enough.In the form of China's large population and thousands of troops in the college entrance examination, students often conduct career education through the words and deeds of schools and teachers and roughly vague theme education.Secondly, more through the Internet, parents independently accept the outside world of information, carried out self-career education.

Snow School and teachers are the main ways for students to obtain the new college entrance examination and career planning problems, while parents are less involved.[3]

Then, schools and teachers account for the main career education area of high school students.In what way are they educated? In addition to the career planning conveyed by teachers' own cognition of society to students, there should also be more detailed courses specifically for career development planning for high school students.For example, vocational planning guidance courses, vocational planning education and labor technology education, vocational planning education and ideological and political education, attach importance to family education, and carry out vocational planning guidance. 
Volume 3 (2021)

The coordination and guidance role of Dong Yan Vocational Planning Education research group is the core and key part of the whole teaching activity. Give the direct guidance and management of the whole teaching activity and adjust the teaching plan of the vocational planning curriculum.[4]

\section{Factors Affecting the Career Development Plan of High School Students}

Although schools and teachers occupy the main body in the education for high school students' vocational development plans.However, in influencing high school students in their career development plans, the family model and self-cognition of family education, family atmosphere account for a more proportion.A family's development state and self-perception of society have played a significant impact on the career development planning of high school students.Zhang Baiyi mentioned that the parents are the children's original teachers, and the parenting style has a profound impact on the future direction of teenagers.Career decision-making self-effectiveness is an individual's confidence in choosing a future major or career.[5]

\section{How to Strengthen the Career Education and Training of High School Students in the Future}

We should start from each subject, find the disadvantages, put forward the solutions, and implement the actions.

From the perspective of school, teacher education.First of all, to put an end to the problem of formal teaching, we must put the career development planning of high school students into the formal teaching system.Formalism teaching cannot be carried out in response to the needs of the government, social supervision and parents.Xu Meina proposed that for middle school students, having the career planning ability directly determines their future direction and development.And middle school is the most important stage of growth and learning in a person's life. Many abilities and qualities are developed at this stage. Therefore, China should formally promote the career planning curriculum in every middle school campus.[6]

From the government level, Cai Qi believes that first of all, the government should strengthen the policy orientation of career planning education, increase financial support and establish supporting service facilities.[7] First, strengthen the policy orientation of career planning education for high school students.Policy support can effectively guide the normal and normalized career planning of high school students.Secondly, to a certain extent, it will deepen the importance of various social subjects to career planning education.II. Increase financial support for the career planning and education of high school students to provide financial support for the career development planning of high school students.III. Establish supporting service institutions and facilities. The development mode of the government as the main body, private participation and market supervision will provide services for career planning for high school students.Adopt modern and new technology, and use electronic information to provide information resources.Cai Qi believes that first of all, the government should strengthen the policy orientation of career planning education, increase financial support and establish supporting service facilities.

From the family level, the family development environment and family education are of great significance to the career development planning of high school students.Parents should strengthen their own learning, can not blindly according to their own development experience to their children heart education.Career education and support should be conducted based according to the comprehensive factors such as changing Times, self-development, and children's self-cognition.Dong Zubao and Ye Shuai put forward that parental guidance and imperceptible family environment have a potential impact on the choice of children's future career.[8] 
Volume 3 (2021)

\section{References}

[1]. During the day Peng. Some Problems and Countermeasures in Career Planning Education for High School Students [J]. Road to Success, 2020 (11): 31-32.

[2]. Wang Xinjuan, Li Zibin. Analysis of the Current Situation of Vocational Planning Education in Rural High School Students [J]. China Rural Education, 2020 (09): 24-25.

[3]. Snow. Research on the Selection of High School Students Based on Vocational Interest in the Background of the New College Entrance Examination [D]. Qufu Normal University, 2019.

[4]. Dong Yan. Educational Practice and Research on Vocational Planning Courses for High School Students [D]. Southwestern Jiaotong University, 2011.

[5]. Zhang Baiyi. Relationship between parenting methods, self-efficacy of career decisions and future career planning [D]. University of Jinan, 2019.

[6]. Xu Meina. Analysis of career education status and Training of career planning ability [J]. China Hightech Zone, 2018 (07): 100.

[7]. Cai Qi. Current Status and Countermeasures of Career Planning Education in High School Students [D].Guangxi Normal College, 2014.

[8]. Dong Zuobao, Ye Shuai. On Education and Guidance on Academic and Career Planning for High School Students [J]. Off-campus Education in China, 2019 (05): 28-29. 